\title{
Evaluation of Lateglacial temperatures in the Southern Alps of New Zealand based on glacier modelling at Irishman Stream, Ben Ohau Range
}

\author{
Alice M. Doughty a,b,*, Brian M. Anderson a , Andrew N. Mackintosh ${ }^{\mathrm{a}, \mathrm{b}}$, Michael R. Kaplan ${ }^{\mathrm{c}}$, \\ Aaron E. Putnam ${ }^{\mathrm{c}, \mathrm{f}}$ \\ ${ }^{a}$ Antarctic Research Centre, Victoria University of Wellington, PO Box 600, Wellington 6140, New Zealand \\ ${ }^{\mathrm{b}}$ School of Geography, Environment and Earth Sciences, Victoria University of Wellington, PO Box 600, Wellington 6140, New Zealand \\ ${ }^{c}$ Geochemistry, Lamont-Doherty Earth Observatory, Palisades, NY 10964, USA \\ ${ }^{\mathrm{d}}$ GNS Science, 1 Fairway Drive, Avalon 5010, PO Box 30-368, Lower Hutt 5040, New Zealand \\ ${ }^{\mathrm{e}}$ GNS Science, 764 Cumberland Street, Dunedin 9016, New Zealand \\ ${ }^{\mathrm{f}}$ Department of Earth Sciences and Climate Change Institute, University of Maine, Orono, ME 04469, USA \\ g 20 Muir Road, Lake Hawea, RD2 Wanaka 9382, New Zealand
} Marcus J. Vandergoes ${ }^{d}$, David J.A. Barrell ${ }^{e}$, George H. Denton ${ }^{f}$, Joerg M. Schaefer ${ }^{c}$, Trevor J.H. Chinn ${ }^{g}$,

\section{A R T I C L E I N F O}

Article history:

Received 5 February 2012

Received in revised form

6 September 2012

Accepted 12 September 2012

Available online $\mathrm{xxx}$

\section{Keywords:}

New Zealand

Southern Alps

Palaeoclimate

Glacier modelling

Lateglacial

Antarctic cold reversal

\begin{abstract}
A B S T R A C T
Climate proxy records from the middle to high latitude Southern Hemisphere indicate that a Lateglacial (15,000-11,500 years ago) climate reversal, approximately coeval with the Antarctic Cold Reversal (ACR), interrupted a warming trend during deglaciation. In New Zealand, some palaeoclimate proxy records indicate a cool episode during the ACR (ca 14,500-12,500 years ago), while others do not express a significant change in climate. Recently published moraine maps and ages present an opportunity to improve the palaeoclimate interpretation through numerical modelling of glaciers. We use a coupled energy-balance and ice-flow model to quantify palaeoclimate from past glacier extent constrained by mapped and dated moraines in the headwaters of Irishman Stream, a high-elevation catchment in the Southern Alps. First, a suite of steady-state model runs is used to identify the temperature and precipitation forcing required to fit the modelled glacier to well-dated Lateglacial moraine crests. Second, timedependent glacier simulations forced by a nearby proxy temperature record derived from chironomids are used to assess the fit with the glacial geomorphic record. Steady-state experiments using an optimal parameter set demonstrate that the conditions under which the 13,000 year old moraine formed were $2.3-3.2{ }^{\circ} \mathrm{C}$ colder than present with the range in temperature corresponding to a $\pm 20 \%$ variance in precipitation relative to the present-day. This reconstructed climate change relative to the present-day corresponds to an equilibrium-line altitude of ca $2000 \pm 40 \mathrm{~m}$ above sea level (asl), which is ca $400 \mathrm{~m}$ lower than present. Time-dependent simulations of glacier length produce ice advance to within $100 \mathrm{~m}$ of the 13,000 year old terminal moraine, indicating that the chironomid-based temperature forcing and moraine record provide consistent information about past climate. Our results, together with other climate proxy reconstructions from pollen records and marine sediment cores, support the notion that temperatures during the ACR in New Zealand were $\sim 2-3{ }^{\circ} \mathrm{C}$ cooler than today.
\end{abstract}

(c) 2012 Elsevier Ltd. All rights reserved.

\section{Introduction}

During the Lateglacial interval $(\sim 15,000-11,500$ years ago or $15-11.5 \mathrm{ka}$ ) in the middle to high latitudes of the southern hemisphere, a warming trend was interrupted by the Antarctic Cold

* Corresponding author. Antarctic Research Centre, Victoria University of Wellington, PO Box 600, Wellington 6140, New Zealand. Tel.: +64 44635233 8391; fax: +64 44635186 .

E-mail address: alice.doughty@vuw.ac.nz (A.M. Doughty).
Reversal (ACR, 14.5-12.5 ka (EPICA Community Members, 2006)). New Zealand is one of the few locations in the southern middle latitudes where Lateglacial moraines exist. Many examples of Lateglacial moraines in the Southern Alps of New Zealand have been identified (Porter, 1975b; Suggate, 1990; Fitzsimons, 1997), mapped (Birkeland, 1982; Barrell et al., 2011), and some have been dated (e.g., Turney et al., 2007; Kaplan et al., 2010; Putnam et al., 2010). Transformation of glacier fluctuation records to climate changes is not a trivial process due to several non-climatic influences and is not readily achievable for some types of glacier (e.g., 
debris-covered or calving (Winkler et al., 2010; Anderson and Mackintosh, 2012; Chinn et al., 2012)). Porter (1975a) estimated that the Lateglacial equilibrium-line altitude (ELA) in the Tasman River catchment was $500 \pm 50 \mathrm{~m}$ lower than modern, based on an accumulation area ratio (AAR) analysis of reconstructed glaciers inside the Birch Hill moraine limit. Other proxy records rarely afford quantitative climate estimates. Besides glacial deposits, records that show a prominent cooling during the Lateglacial include sea surface temperature reconstructions from around New Zealand (Pahnke et al., 2003; Barrows et al., 2007; McGlone et al., 2010), pollen records from upland locations in New Zealand (Burrows and Russell, 1990; McGlone, 1995; Newnham and Lowe, 2000; Turney et al., 2003; McGlone et al., 2004; Vandergoes et al., 2008), and chironomid-derived temperature reconstructions (Vandergoes et al., 2008). Less pronounced climate reversals within or overlapping with the ACR period have also been inferred based on other pollen (Newnham et al., 2007, in this issue) and speleothem (Williams et al., 2005) records (see also Alloway et al. (2007)). In this paper, we aim to improve our understanding of the Lateglacial climate event in New Zealand using glacier modelling techniques.

\subsection{Glaciers as a climate proxy}

Glacier extent depends on the balance between accumulation and ablation (Oerlemans, 2001, 2005). Moraine positions in mountainous regions provide evidence of former glacier extents and may be used to infer past climates. Glacial geomorphic mapping of the central South Island of New Zealand (Barrell et al., 2011) has yielded a high-quality constraint on past ice extents, and several surface exposure dating studies provide ages for the culmination of Lateglacial ice advances (Ivy-Ochs et al., 1999; Kaplan et al., 2010; Putnam et al., 2010).

We present an application of a 2-D ice-flow and energy massbalance model (EBM) to reconstruct temperature and precipitation values for the ACR. We apply these models to a glacier whose extent is delineated by moraines mapped by Kaplan et al. (2010) in the headwaters of Irishman Stream in the central Southern Alps of New Zealand and compare our findings to their AAR reconstructions and other climate proxy records. In experiment 1 , we explore the different combinations of temperature and precipitation required to produce a steady-state glacier that most closely matches the moraine record, taking account of uncertainties associated with model parameter choices. In experiment 2, we use a chironomidderived temperature reconstruction (Vandergoes et al., 2008) to drive our glacier model and test if this climate forcing produces ice extents compatible with the moraine record (Kaplan et al., 2010).

\subsection{Study area}

The South Island of New Zealand is dominated by the high axial range of the Southern Alps, which impedes the prevailing westerly winds, resulting in a steep west to east precipitation gradient (Griffiths and McSaveney, 1983; Henderson and Thompson, 1999). Glaciers with fast response times to climate perturbations are abundant in the central Southern Alps due to high snowfall rates and steep mountain slopes (Chinn, 1996; Fitzharris et al., 1999). We focus on moraines deposited in the headwaters of Irishman Stream $\left(43^{\circ} 59^{\prime} 30^{\prime \prime} \mathrm{S}, 170^{\circ} 03^{\prime} 00^{\prime \prime} \mathrm{E}\right)$, located in the Ben Ohau Range (Fig. 1) (McGregor, 1967; Birkeland, 1982; Kaplan et al., 2010). The dated glacial deposits lie at the edge of a cirque, referred to here as Irishman basin, that comprises the upper $2 \mathrm{~km}$ of Irishman Stream valley. The basin floor, for the most part, slopes gently $\left(\sim 15^{\circ}\right)$ towards the southwest.

Aside from the mapped and dated moraine sequence, there are several reasons why Irishman basin is well-suited for this study. First, Irishman basin is located $<30 \mathrm{~km}$ to the southeast of the most glacierised section of the Southern Alps and is affected by the same regional atmospheric circulation, including the prevailing westerly

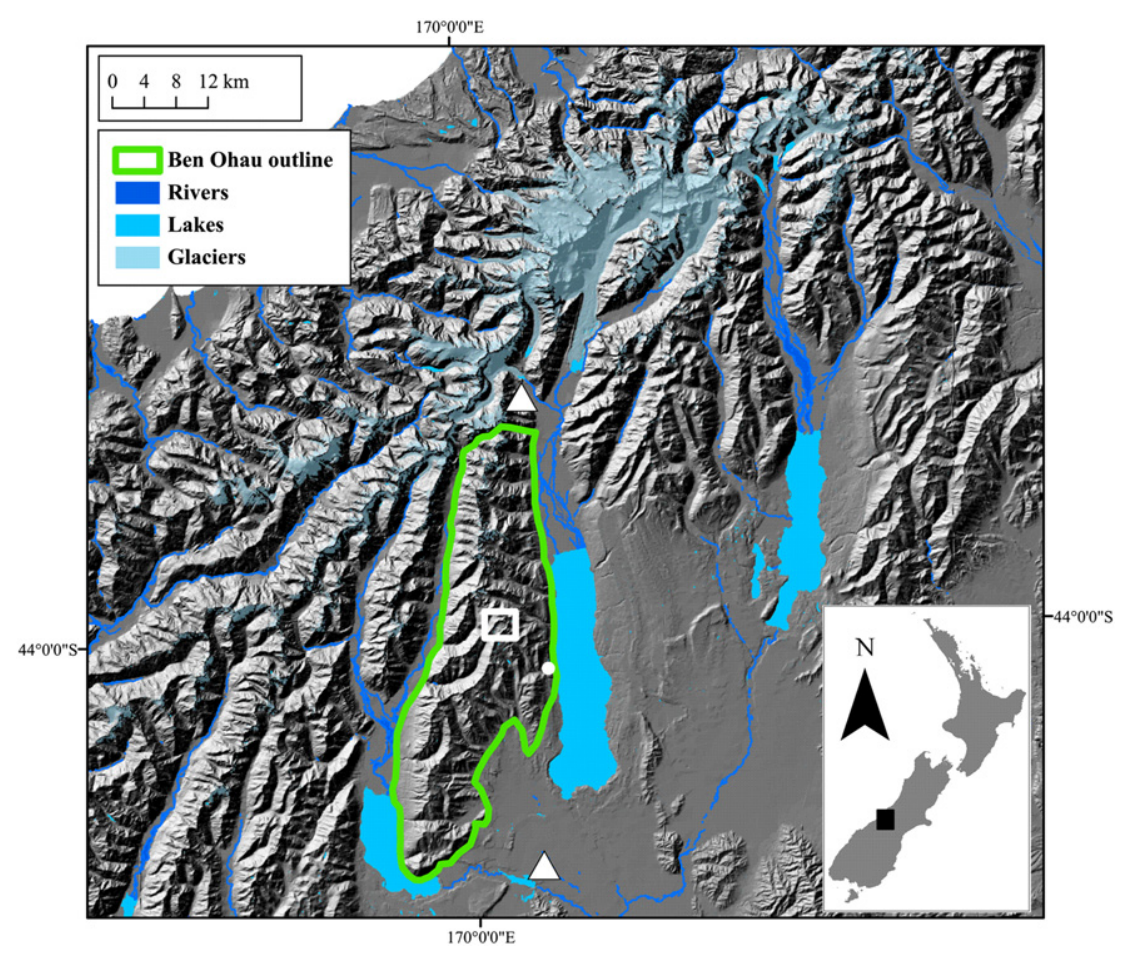

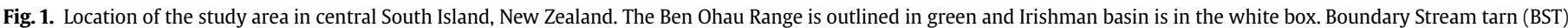

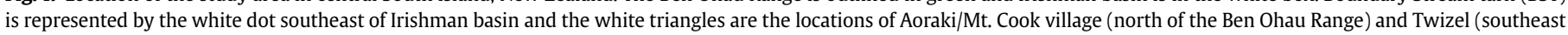
of Ben Ohau Range). (For interpretation of the references to colour in this figure legend, the reader is referred to the web version of this article.) 
winds (Kaplan et al., 2010; Chinn et al., 2012). Second, Irishman basin lacks complex terrain and has a shallow gradient, making our use of the shallow ice approximation equations an appropriate model choice (Leysinger Vieli and Gudmundsson, 2004). Third, the basin supported a single glacier with no tributaries, making it a very simple glacier system for ice reconstructions. Fourth, the presentday digital elevation model provides an appropriate topographic boundary condition for the numerical model because the basin is presently ice-free, and the visible bedrock knobs and outcrops on the valley floor indicate little sediment accumulation and hence minor topographic change since deglaciation. Moreover, the $15^{\circ}$ down-valley slope of the basin floor precludes the former existence of large proglacial lakes and calving ice termini. Therefore, we assume glacier fluctuations in this valley directly relate to changes in atmospheric conditions and hence climate over this part of the South Island.

There are several reasons why we believe that the Irishman basin glacier at $13 \mathrm{ka}$ did not contain a significant surface debris cover. Although there are rock glaciers at the headwalls of Irishman basin and the basin has a veneer of rock debris, through which bedrock hills are visible, the Lateglacial moraine is not particularly large, especially the left lateral segment (Kaplan et al., 2010). These features suggest that debris cover of past glaciers in this valley was not sufficient to dramatically affect the albedo/energy balance. Also, present-day Glenmary Glacier, $12 \mathrm{~km}$ west of Irishman basin, is an example of a small cirque glacier in a similar setting to that of the $13 \mathrm{ka}$ Irishman glacier that is relatively free of debris-cover.

There are no long-term climate data from Irishman basin. We characterised the present climate by interpolating between data from multiple low-elevation stations and measurements from a temporary climate station that we installed in Irishman basin $\left(43^{\circ} 59^{\prime} 30^{\prime \prime} \mathrm{S}, 170^{\circ} 2^{\prime} 57^{\prime \prime} \mathrm{E}, 2010 \mathrm{~m}\right.$ asl). The station operated over an 11 month period, March 2010-January 2011, so February values are inferred to be the same as January temperature values to calculate an annual mean temperature of $1.2{ }^{\circ} \mathrm{C}$. Hourly temperatures from the temporary station were averaged into monthly mean temperatures (Table 1 ), with the warmest month at $6.2{ }^{\circ} \mathrm{C}$ (January, 2011) and the coolest month at $-6.1^{\circ} \mathrm{C}$ (June, 2010).

Interpolated precipitation data suggest an annual mean of $1240 \mathrm{~mm}$ (Stuart, 2011) for this location. Although the annual total precipitation surface and monthly mean interpolated precipitation data are based on data from many long-term rain gauges located in the central Southern Alps, we use two nearby stations to provide an indication of precipitation variation at Irishman basin. Mean precipitation data from Twizel, $30 \mathrm{~km}$ to the south (Station numbers $4995,4996,4997$ ), from 1973 to 1997 is $\sim 610 \mathrm{~mm} \mathrm{a}^{-1}$ with a standard deviation of $\pm 110 \mathrm{~mm} \mathrm{a}^{-1}$ (18\%) (National Institute for Water and Atmospheric Research (NIWA), Retrieved 20092011). Likewise, mean precipitation data from Aoraki/Mt. Cook village, $30 \mathrm{~km}$ to the north (Station numbers 18125, 4591, 4593), from 1930 to 2011 is $\sim 4100 \mathrm{~mm} \mathrm{a}^{-1}$ with a standard deviation of

Table 1

Measured monthly mean temperatures $\left(T_{\text {meas }}\right)$ and calculated temperature lapse rates $(\mathrm{d} T / \mathrm{d} z)$ for each month based on Irishman basin climate station data (2010$2011,43^{\circ} 59^{\prime} 30^{\prime \prime} \mathrm{S}, 170^{\circ} 02^{\prime} 57^{\prime \prime} \mathrm{E}, 2010 \mathrm{~m}$ asl). Annual mean measured temperature is $\pm 1.2{ }^{\circ} \mathrm{C}$ (assuming a value of $6.2{ }^{\circ} \mathrm{C}$ for February) and the annual mean lapse rate is $-5.4^{\circ} \mathrm{C} \mathrm{km}^{-1}$.

\begin{tabular}{lclcccc}
\hline Month & Jan & Feb & Mar & Apr & May & Jun \\
\hline$T_{\text {meas }}\left[{ }^{\circ} \mathrm{C}\right]$ & 6.2 & - & 4.9 & 3.1 & -1.1 & -6.1 \\
$d T / \mathrm{d} z\left[{ }^{\circ} \mathrm{C} \mathrm{km}{ }^{-1}\right]$ & -6 & $-6^{\mathrm{a}}$ & -5.5 & -5.5 & -5 & -4 \\
\hline Month & Jul & Aug & Sep & Oct & Nov & Dec \\
\hline$T_{\text {meas }\left[{ }^{\circ} \mathrm{C}\right]}$ & -6 & -3.6 & -1.5 & 0.8 & 4.9 & 6 \\
$\mathrm{~d} T / \mathrm{d} z\left[{ }^{\circ} \mathrm{C} \mathrm{km}{ }^{-1}\right]$ & -3.5 & -5.5 & -6.5 & -5.5 & -5.5 & -6 \\
\hline
\end{tabular}

a The February $\mathrm{d} T / \mathrm{d} z$ was set equal to the January value because of a data gap. $\pm 900 \mathrm{~mm} \mathrm{a}^{-1}$ (22\%) (NIWA, Retrieved, 2009-2011) (Twizel and Aoraki/Mt. Cook village locations are shown in Fig. 1). We consider the characteristic present-day precipitation variability to be $\sim 20 \%$, based on the standard deviation from these stations.

\section{Modelling glacier extent}

We used a simple iterative modelling approach to estimate palaeoclimate conditions based on modelled glacier extent. This strategy is similar to those employed in previous studies (Plummer and Phillips, 2003; Hubbard et al., 2005; Kessler et al., 2006; Laabs et al., 2006) except that our 2-D ice-flow model is coupled with a spatially-distributed EBM. Our EBM/2-D ice-flow combination is simple enough to simulate mapped ice extents quickly (steadystate runs take less than an hour on a desktop computer), yet is complex enough to account for shading, aspect, valley slope, and local climate.

A digital elevation model was used to provide surface elevation throughout the model domain. This model was produced from $20 \mathrm{~m}$ interval topographic contours and spot heights on published 1:50,000-scale (NZMS260 series) topographic maps published by Land Information New Zealand. We simulated the 13 ka Irishman glacier at $25 \times 25 \mathrm{~m}$ gridded horizontal resolution, with all simulations starting from an ice-free basin. The model domain covers a $5 \times 6 \mathrm{~km}$ area centred over Irishman basin.

\subsection{Input data}

Thirty years (1981-2010) of daily climate data were converted into monthly means for each grid cell in the model domain. We calculated climate data grids from several different sources depending on availability and reliability. First, daily climate data of relative humidity, solar radiation, temperature, and precipitation came from the NIWA CliFlo Database (NIWA, Retrieved, 20092011). Relative humidity and solar radiation grids came from the virtual climate station network climate grid interpolations, available directly from the NIWA CliFlo website. The NIWA climate grids were not used for temperature because the data contain some biases in mountainous terrain (Anderson and Mackintosh, 2012). Instead, we created interpolated temperature surfaces using data from multiple, surrounding, low-elevation stations (NIWA, Retrieved, 2009-2011). To make the interpolation surface, we took daily temperature data from each station $\left(T_{\mathrm{st}}\right.$ in $\left.{ }^{\circ} \mathrm{C}\right)$, the monthly lapse rate $(\mathrm{d} T / \mathrm{d} z$ in $\left.{ }^{\circ} \mathrm{C} \mathrm{km}^{-1}\right)$, and station elevation $\left(z_{\mathrm{st}}\right.$ in $\left.\mathrm{m}\right)$ to create a 'reference' temperature $\left(T_{\mathrm{r}}\right.$ in $\left.{ }^{\circ} \mathrm{C}\right)$ at sea level using:

$T_{\mathrm{r}}=T_{\mathrm{st}}-\frac{\mathrm{d} T}{\mathrm{~d} z} \frac{z_{\mathrm{st}}}{1000}$

Daily reference temperature surfaces were interpolated at sea level in the horizontal plane across the model domain (Tait and Zheng, 2007). Modelled temperature $\left(T\right.$ in $\left.{ }^{\circ} \mathrm{C}\right)$ in any grid cell was calculated using Equation (2), with the grid cell reference temperature, the month's lapse rate, and the elevation value of the grid cell ( $z$ in $\mathrm{m}$ ). Each modelled past temperature change $(\Delta T)$ is an additive change to the temperature $(T)$ in each grid cell and is uniformly applied across the domain:

$T=T_{\mathrm{r}}+\frac{\mathrm{d} T}{\mathrm{~d} z} \frac{z}{1000}+\Delta T$

We calculated and used variable monthly temperature lapse rates (Fig. 2 and Table 1 ), which were determined by minimising the mismatch between Irishman temporary climate station temperature data and an interpolated temperature grid. This temporally varying lapse rate attempts to account for pervasive 


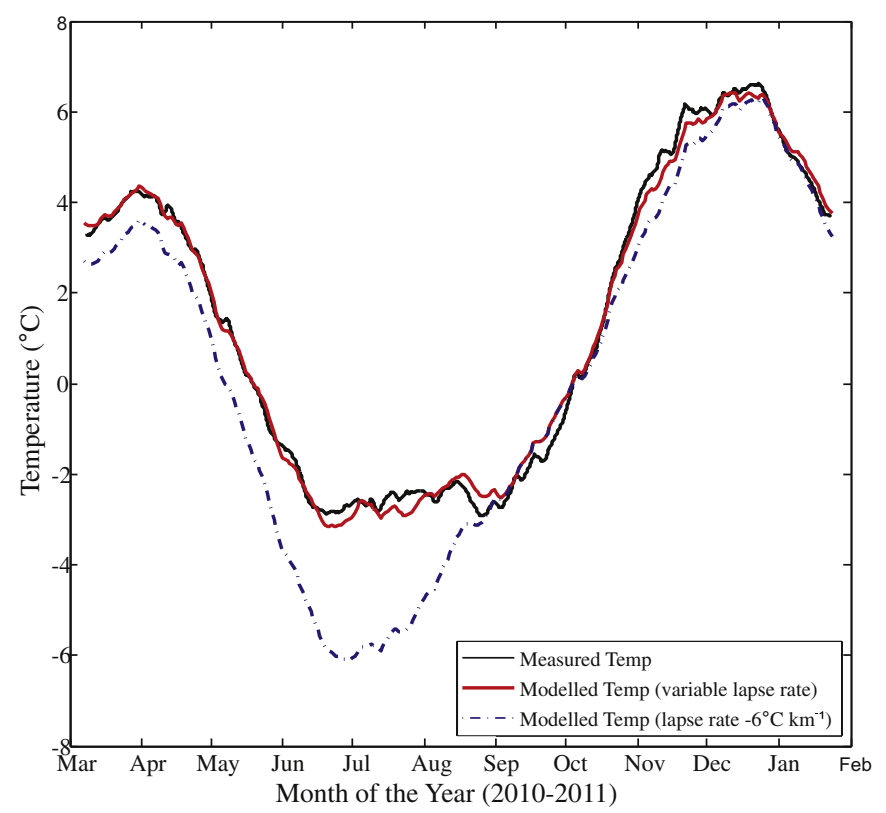

Fig. 2. Modelled versus measured temperatures at the location of a climate station in Irishman basin. Modelled temperature values (daily interpolated temperature, $T$, smoothed with a thirty-day running mean) were interpolated from climate stations at $<800 \mathrm{~m}$ asl over the 2010-2011 interval. Measurements (black line) are compared to modelled temperatures that were calculated using a monthly varying lapse rate (red line) and a constant lapse rate (blue dashed). Using a constant lapse rate achieves a poor match, especially during winter months (Jun-Sep). (For interpretation of the references to colour in this figure legend, the reader is referred to the web version of this article.)

valley-scale temperature inversions which occur in winter in this region (Fig. 2). Observed and calculated 'clear-sky' solar radiation were used to calculate cloudiness, following Hock (2005) and Anderson et al. (2010).

Second, reanalysis data from the National Centers for Environmental Predication (NCEP) for present-day wind at the $850 \mathrm{hPa}$ level (1981-2010) (Kalnay et al., 1996) were scaled to match observed wind speed and were applied uniformly across the model domain. Wind speeds are not modified for the complex topography and we assume wind speed distribution is uniform over the domain. These data were converted into monthly mean gridded wind speed. Further discussion of these datasets and the rationale for using them is provided in Anderson and Mackintosh (2012).

The third source of input climate data came from an annual mean precipitation surface (Stuart, 2011) based on rain gauge data, from 1971 to 2000, spatially distributed around the Southern Alps to capture the steep precipitation gradient. The interpolated precipitation (Anderson et al., 2010) amount at each grid cell was calculated at monthly mean values from daily measured rainfall at lowland stations (NIWA). The interpolated data were guided by an annual mean precipitation surface (Stuart, 2011).

Modelled past precipitation change $(\Delta P)$ is calculated as a percentage from present day, where present-day precipitation is $\Delta P=0 \%$ change, doubling present-day precipitation is $\Delta P=+100 \%$ change, and halving present-day precipitation is $\Delta P=-50 \%$ change. $\Delta P$ represents the change in precipitation reaching the site, which could be a result of regional changes in annual precipitation and/or changes in the amount of snow settling within Irishman basin as a result of increasing or decreasing snow transport.

\subsection{The energy-balance model}

We developed a spatially-distributed EBM that uses the specified topography, monthly interpolated meteorological input, ice thickness at each monthly time-step, and prescribed climate perturbations to calculate annual mass balance at each grid cell. The resulting mass balance grid was then used as a boundary condition in our ice-flow model (Section 2.3). Several other workers have employed 1- and 2-D models based on similar sets of equations (e.g., Oerlemans, 1992; Plummer and Phillips, 2003; Hock, 2005). We followed an EBM scheme described in Anderson et al. (2010) and Anderson and Mackintosh (2012), except ours used a monthly timestep and updates mass balance once every 5 or 20 model years (transient and steady-state respectively). The model calculated the energy available for melt $\left(Q_{M}\right)$ using the following equation:

$Q_{\mathrm{M}}=I(1-\alpha)+L \downarrow+L \uparrow+Q_{\mathrm{H}}+Q_{\mathrm{E}}+Q_{\mathrm{G}}+Q_{\mathrm{R}}$

where $I$ is the incoming shortwave radiation, $\alpha$ is the surface albedo, $L \downarrow$ is the incoming longwave radiation, $L \uparrow$ is the outgoing longwave radiation, $Q_{H}$ and $Q_{E}$ are the sensible and latent heat fluxes, $Q_{G}$ is the ground heat flux, and $Q_{R}$ is the heat supplied by rain. All heat exchanges are in units of $\mathrm{W} \mathrm{m} \mathrm{m}^{-2}$. Positive values of radiative and turbulent fluxes indicate a gain of energy for melting of the snowpack, and negative values indicate a loss of energy. $Q_{G}$ was set at $1 \mathrm{~W} \mathrm{~m}^{-2}$ (Neale and Fitzharris, 1997) and $Q_{R}$ was calculated assuming that precipitation is the same temperature as the air (Oerlemans, 1992).

Incoming shortwave radiation $(I)$ was comprised of direct and diffuse components following Oerlemans (1992). Cloudiness (see above) was included in the insolation calculations following Hock (2005) and Anderson et al. (2010). Insolation values for the steadystate simulations were calculated for $13 \mathrm{ka}$ (Berger and Loutre, 1991; Eisenman and Huybers, 2006). The albedo parameterisation $(\alpha)$ was based on a background albedo profile, which shows albedo increasing with altitude and snow thickness, both dependent on the modelled ELA, following Oerlemans (1992). Longwave and shortwave radiation distribution were calculated to include the view field of the surrounding topography from the cell and cloudiness following Plummer and Phillips (2003) and Anderson et al. (2010). Turbulent heat fluxes $\left(Q_{H}\right.$ and $\left.Q_{E}\right)$, which can make up half or more of the energy available for melt in maritime environments (Anderson and Mackintosh, 2012), were calculated using the bulk method (Klok and Oerlemans, 2002; Oerlemans and Grisogono, 2002) following Oerlemans (1992). The turbulent heat calculations used different roughness lengths for snow and ice surfaces and the Richardson stability criterion was applied for stable stratification conditions (Oerlemans, 1992; Hock, 2005; Anderson et al., 2010).

Snow accumulation occurred in the model when the temperature at each grid cell was at or below a snow/rain temperature threshold. The snow temperature threshold $\left(T_{\mathrm{S}}\right)$ was set to $1{ }^{\circ} \mathrm{C}$ (Anderson et al., 2006). We did not take possible surface debris cover effects into account in these palaeo-simulations, although this cover was likely insignificant when Irishman glacier filled much of the basin at the ACR extent as suggested by the present geomorphology and previous glacier reconstructions (Kaplan et al., 2010).

Mass balance of the simulated glacier was calculated by subtracting the mass of possible melt from the mass of snow accumulation at each grid cell. The mass balance was recalculated every 20 model years in steady-state runs (every 5 model years in transient runs) while the ice-flow model ran. Coupling the models allowed the parameters sensitive to topography or the presence of ice (i.e., albedo, turbulent heat fluxes, shading, longwave radiation) to readjust as the ice thickness and extent evolved.

\subsection{The ice-flow model}

The ice-flow model employed in this study is a 2-D shallow ice approximation model, with an explicit time-step, similar to 

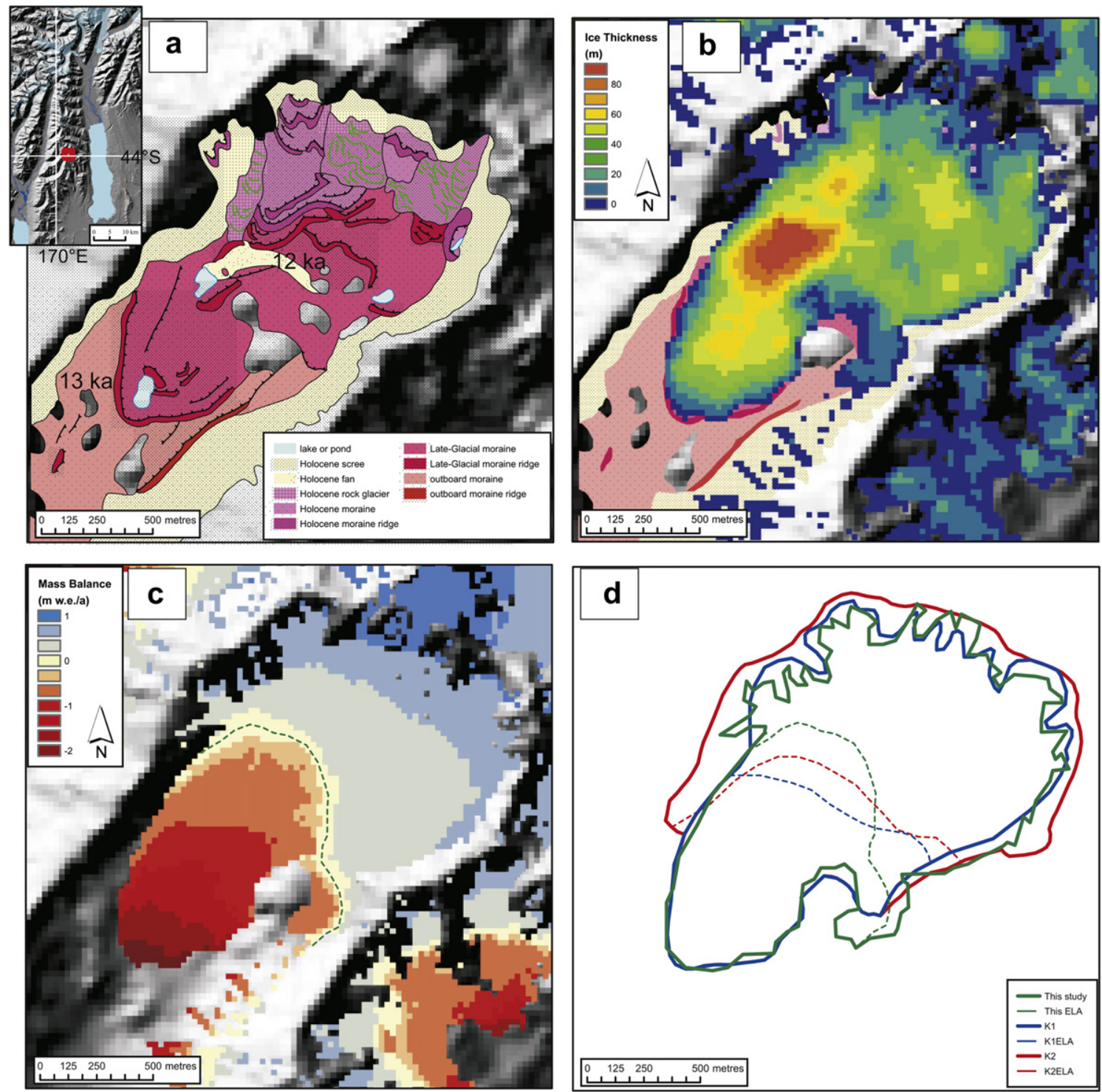

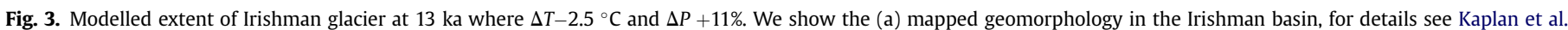

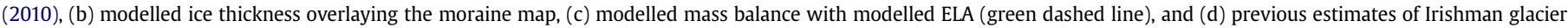

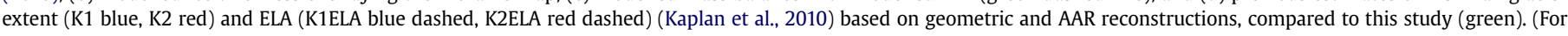
interpretation of the references to colour in this figure legend, the reader is referred to the web version of this article.)

Plummer and Phillips (2003) and Kessler et al. (2006). The model used the basic mass continuity equation:

$\frac{\mathrm{d} H}{\mathrm{~d} t}=M-\nabla \cdot \vec{q}$

where $H$ is the ice thickness, $t$ is time, $\vec{q}$ is ice flux, and $M$ is the mass balance, which was calculated using the EBM described in Section 2.2. The flux divergence was calculated using a 2-D finitedifference scheme. The vertically-averaged ice velocity from internal deformation was calculated using the shallow ice approximation (Paterson, 1994):

$\vec{U}_{\mathrm{d}}=\frac{2}{5} A H \vec{\tau}_{\mathrm{b}}^{n}$

where $A$ is the coefficient of Glen's flow law, set to $1 \mathrm{e}^{-17} \mathrm{~Pa}^{-3} \mathrm{a}^{-1}$, $\vec{\tau}_{\mathrm{b}}$ is the gravitational driving stress $\left(\vec{\tau}_{\mathrm{b}}=\rho g H \nabla z\right)$, and $n$ is Glen's flow law exponent, set to 3. The sliding velocity follows the empirical formulation of Kessler et al. (2006):

$\vec{U}_{\mathrm{s}}=U_{\mathrm{c}} \mathrm{e}^{1-\frac{\tau_{\mathrm{c}}}{\vec{\tau}_{\mathrm{b}}}}$

where $U_{\mathrm{c}}$ is a typical sliding velocity $\left(20 \mathrm{~m} \mathrm{a}^{-1}\right)$ and $\tau_{\mathrm{c}}$ is the gravitational driving stress $\left(10^{5} \mathrm{~Pa}\right)$ that results in $\vec{U}_{\mathrm{s}}$.

The continuity equation (Equation (4)) was used to evolve the glacier geometry through time by calculating the ice velocity $\left(\vec{U}_{\mathrm{d}}+\right.$ $\vec{U}_{s}$ ) on a square grid that is offset from the points at which ice thickness is known. The flux gradients were then used to calculate the updated ice thickness using a forward explicit time-step. The evolving time-step was calculated from the stability condition from Hindmarsh and Le Meur (2001).

One way to quantify the error associated with the ice-flow model is to find the proportion of integrated mass balance for a modelled glacier in equilibrium relative to the total accumulation rate. The integrated mass balance over the glacier surface, for the 
Irishman glacier while it is in equilibrium (where $\Delta T=-2.5^{\circ} \mathrm{C}$ and $\Delta P=11 \%)$, is $-17.4 \mathrm{~mm} \mathrm{a}^{-1}$. The integrated total annual accumulation for the glacier is $815 \mathrm{~mm} \mathrm{a}^{-1}$. The mass balance divided by the accumulation total gives an estimate of the proportion of mass generated by the flow model $(2.1 \%)$. The proportion is low, indicating that the ice-flow model is not a significant source of error for the palaeoclimate estimates.

The assumptions that underlie the shallow ice approximation are less valid in parts of the model domain where bed slope and glacier aspect ratio are high (Le Meur et al., 2004), however, Irishman glacier overall has a low aspect ratio and a low ice surface gradient. We consider the primary control on glacier evolution in Irishman basin to be the mass balance (Leysinger Vieli and Gudmundsson, 2004), and thus the shallow ice approximation is appropriate for our investigation. A summary of the parameter values used in the climate data interpolation, energy balance, and ice-flow models is given in Table 2. Most values were taken from published literature and value ranges in the sensitivity tests are used to calculate their effect on results.

\subsection{Steady-state simulations}

In experiment 1 , incremental changes in temperature relative to modern day $(\Delta T)$ from -1.5 to $-3.5^{\circ} \mathrm{C}$, and in precipitation relative to modern day $(\Delta P)$ from $-50 \%$ to $+200 \%$ were applied uniformly across the year and domain to force the EBM/2-D ice-flow model from initial ice-free conditions. We assumed that the glacier was in or near equilibrium with the climate when it deposited the continuous moraine, and thus steady-state simulations represent a possible climate for a particular glacier size. The resulting steadystate ice extent was then compared to the moraine position, where a good match shows the distance between them being less than two grid cells $(<50 \mathrm{~m})$. These iterations were used to derive a $\Delta P-$ $\Delta T$ curve, where combinations of $\Delta P-\Delta T$ on that curve produced a glacier extent that fitted the moraine position. Each steady-state simulation ran for 240 model years, which is greater than the maximum time for any $\Delta P-\Delta T$ combination for the 13 ka glacier to adjust to equilibrium starting from ice-free conditions. The EBM ran once every 20 model years to recalculate the glacier mass balance. These simulations used values from our optimal parameter set (Table 2).

In order to assess the impact of parameter choices on our results, the following parameters were systematically explored: $T_{\mathrm{s}}, \alpha_{\mathrm{snow}}$, $Z_{\text {ice, }} Z_{\text {snow, }} U_{c}$, and $A$. In each case the model ran using the optimal parameter set with the exception of the parameter we were testing. These tests were done with a similar model setup to experiment 1 , each running for 240 model years, changing $\Delta P-\Delta T$ combinations

\section{Table 2}

Model parameter values. These values define our optimal parameter set, meaning they come from previously published studies optimal for modelling and/or are specific to the site location. Our sensitivity tests use these values, changing one value at a time to understand each parameter's influence on our climate reconstruction.

\begin{tabular}{|c|c|c|c|}
\hline Parameter name & Symbol & Value & Source \\
\hline Snow albedo - ELA related & $\alpha_{\text {snow }}$ & 0.72 & Oerlemans (1992) \\
\hline $\begin{array}{l}\text { Snow/rain temperature } \\
\text { threshold }\end{array}$ & $T_{\mathrm{s}}$ & $1^{\circ} \mathrm{C}$ & Anderson et al. (2006) \\
\hline Temperature lapse rates & $\mathrm{d} T / \mathrm{d} z$ & see Table 1 & This study \\
\hline $\begin{array}{l}\text { Roughness parameter } \\
\text { for ice }\end{array}$ & $Z_{\text {ice }}$ & $0.004 \mathrm{~m}$ & $\begin{array}{l}\text { Anderson and } \\
\text { Mackintosh (2012) }\end{array}$ \\
\hline $\begin{array}{l}\text { Roughness parameter } \\
\text { for snow }\end{array}$ & $Z_{\text {snow }}$ & $0.001 \mathrm{~m}$ & Brock et al. (2006) \\
\hline Typical sliding velocity & $U_{\mathrm{c}}$ & $20 \mathrm{~m} \mathrm{a}^{-1}$ & Kessler et al. (2006) \\
\hline Glen's flow law coefficient & $A$ & $1 \mathrm{e}^{-17} \mathrm{~Pa}^{-3} \mathrm{a}^{-1}$ & Paterson (1994) \\
\hline Wind & & Reanalysis & Kalnay et al. (1996) \\
\hline Maximum snow thickness & & 5 m w.e. & \\
\hline
\end{tabular}

until the glacier reached within $50 \mathrm{~m}$ of the moraine. In the sensitivity tests, we created a new $\Delta P-\Delta T$ curve for each tested parameter (Fig. 4).

\subsection{Transient runs}

In experiment 2, transient model runs were forced using chironomid-derived mean summer temperature reconstructions from sediments at Boundary Stream tarn (BST, $44^{\circ} 02^{\prime} \mathrm{S}, 170^{\circ} 07^{\prime} \mathrm{E}$, $830 \mathrm{~m}$ asl) located $7 \mathrm{~km}$ southeast of Irishman basin, that span the Lateglacial time (Vandergoes et al., 2008) (Fig. 1). The age model at the BST site is derived from Bayesian modelling of 17 radiocarbon dates, calibrated using IntCal04 (Vandergoes et al., 2008). The chironomid record shows a period of temperature instability between 14.2 and $13.2 \mathrm{ka}$, including a maximum cool spike between 2 and $3{ }^{\circ} \mathrm{C}$ below present values (Vandergoes et al., 2008). Particular strengths of the BST record are that chironomids are sensitive to mean summer temperatures (DieffenbacherKrall et al., 2007), the site lies close to Irishman basin, and the chironomid record is compatible with pollen-based palaeoclimate proxies from the same core. Although the chironomid temperature reconstruction describes mean summer temperature values, we apply it to our model as mean annual temperature changes. The sample specific error on the chironomid-derived temperatures is $\pm 1.4{ }^{\circ} \mathrm{C}$. Vandergoes et al. (2008) reconstructed summer temperatures from chironomids using two different modern-day chironomid-temperature calibration models and published both the raw and smoothed data from these models. They drew their conclusions (as much as $\sim 2-3{ }^{\circ} \mathrm{C}$ cooling during the ACR) from the smoothed data of the partial least squares (PLS-smooth) model. We used all four temperature reconstructions (PLS-raw, PLS-smooth, weighted average partial least squares (WAPLS)raw, and WAPLS-smooth) to drive our EBM/2-D ice-flow model $\Delta T$ values. Each simulation was compared to the moraine sequence dated by Kaplan et al. (2010) to determine the best fit out of the four temperature reconstructions.

Temperatures were interpolated between the data points in each reconstruction from Vandergoes et al. (2008) using nearest

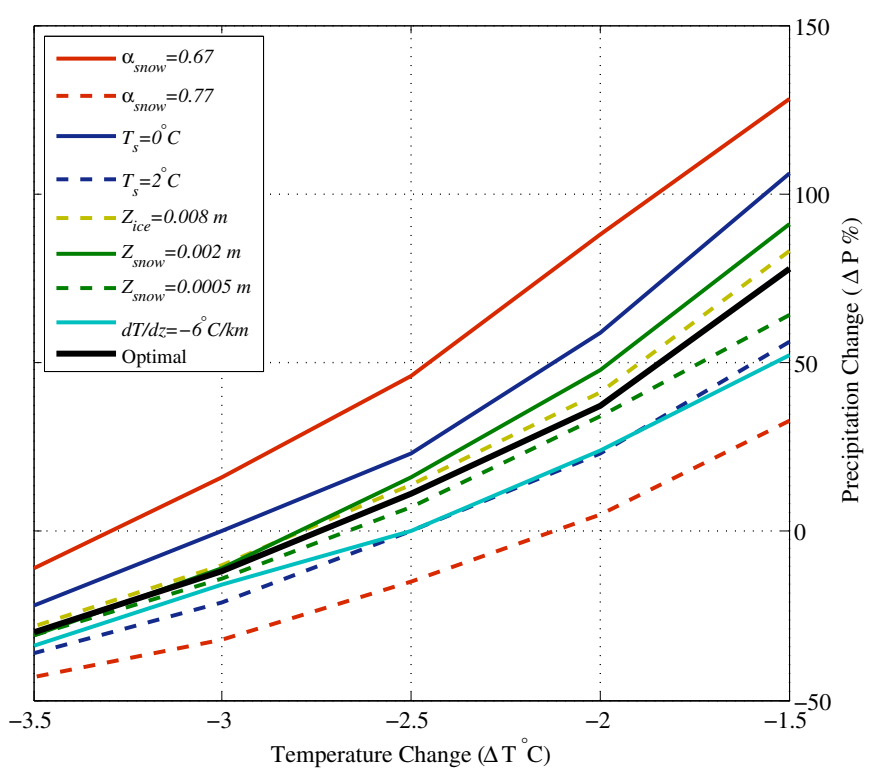

Fig. 4. Experiment 1 results - Inferred $\Delta P-\Delta T$ reconstructions showing the sensitivity of the climate reconstruction to chosen parameter values. Curves identical to the 'Optimal' curve are not shown $\left(I, U_{\mathrm{c}}, A\right.$, and $\left.Z_{\text {ice }}=0.002 \mathrm{~m}\right)$. The $x$-intercepts of the different curves are reported in Table 3. 
neighbour interpolation. Precipitation was set to $0 \%$ change (present-day) for all transient runs. Each simulation ran for 4000 model years (15-11 ka) and the EBM ran once every 5 model years to recalculate the energy balance on the evolving ice surface including differences in insolation $(I)$ due to changing orbital parameters during the period 15-11 ka.

\section{Results}

\subsection{Experiment 1: steady-state simulations of the ACR Irishman glacier extent}

The first experiment of our investigation involved carrying out a suite of equilibrium runs at set $\Delta P-\Delta T$ combinations to identify those that produced a good match with the Irishman basin $13 \mathrm{ka}$ moraine position (Fig. 3a and b). Fig. 3b shows the fit between modelled ice thickness and the moraine record during a single simulation where $\Delta T$ is $-2.5{ }^{\circ} \mathrm{C}$ and $\Delta P$ is $+11 \%$. The modelled Irishman glacier at the $13 \mathrm{ka}$ extent has an area of $\sim 1.8 \mathrm{~km}^{2}$, volume of $\sim 0.15 \mathrm{~km}^{3}$ and a maximum thickness of $100 \mathrm{~m}$. The modelled glacier response time to a $1{ }^{\circ} \mathrm{C}$ decrease in $\Delta T$ is $10^{2}$ model years, suggesting that the glacier would respond to centennial scale shifts in climate, rather than decadal. The relatively long response time is consistent with the low slope angle of Irishman basin and a relatively low mass turnover.

Fig. 3c shows the mass balance of Irishman glacier when $\Delta T$ is $-2.5{ }^{\circ} \mathrm{C}$ and $\Delta P$ is $+11 \%$. Mass balance ranges from $1 \mathrm{~m}$ w.e. accumulation at highest elevations to $-2 \mathrm{~m}$ w.e. ice melt at the terminus. The modelled ELA (mean elevation where mass balance equals zero) in this simulation is $2000 \pm 40 \mathrm{~m}$ asl. The present-day ELA is above the elevation of Irishman basin and has been extrapolated to $>2300 \mathrm{~m}$ asl from present-day glacier snowlines (Porter, 1975b; Chinn, 1995; Lamont et al., 1999; Mathieu et al., 2009). To assess this estimate and to compare our palaeo-ELA with that of today, we applied the same climate data interpolation scheme and energy balance model to an idealised, cone-shaped and ice-covered mountain rising to $2500 \mathrm{~m}$ asl at the same location as Irishman basin. The modelled present-day ELA for Irishman basin derived using this method is $\sim 2400 \pm 40 \mathrm{~m}$ asl, only $\sim 100 \mathrm{~m}$ above the highest parts of the headwall of Irishman basin. Therefore, the ELA lowering that corresponds to the ACR event is $\sim 400 \pm 40 \mathrm{~m}$.

Fig. 4 displays the $\Delta P-\Delta T$ curves using the optimal parameter set (Table 2) and variations in parameters. A similar glacier geometry to that shown in Fig. 3b will form with any $\Delta P-\Delta T$ combination on the black curve in Fig. 4, although the glaciers resulting from a larger precipitation increase are slightly thicker. With no change in temperature, a precipitation increase of $241 \%$ is necessary to simulate the moraine position (not shown in Fig. 4).

Varying the $T_{\mathrm{S}}$ and $\alpha_{\text {snow }}$ individually has the largest impact of all parameters on our climate results. Changes of $\pm 1{ }^{\circ} \mathrm{C}$ in the $T_{\mathrm{S}}$ alone influences the temperature reconstruction by $\pm 0.3{ }^{\circ} \mathrm{C}$. Likewise, changing the $\alpha_{\text {snow }}$ alone by \pm 0.05 modifies $\Delta T$ by $\pm 0.6^{\circ} \mathrm{C}$. Despite the effects of parameter choice on our climate reconstructions, the overall conclusions do not change. Variations in other parameters have smaller influences on the $\Delta P-\Delta T$ curve. For example, varying the local summer insolation $(I)$ between low (18 ka) and high (10 ka) values makes no direct difference in the modelled glacier extent or climate reconstruction.

Table 3 lists the parameters, the values used in the sensitivity tests, and the $\Delta T$ needed to model Irishman glacier without a change in precipitation. The model-derived $\Delta T$ ranges from -3.3 to -2.1 with the optimal parameter set (Table 2) curve crossing at $-2.7^{\circ} \mathrm{C}$ when $\Delta P$ is set to zero. We consider the temperature uncertainty $\left(0.6{ }^{\circ} \mathrm{C}\right)$ as half the range of temperature values $(-3.3$ to $-2.1^{\circ} \mathrm{C}$ ) shown in Fig. 4 . A smaller temperature change requires
Table 3

Parameter name, symbol, value, and the $\Delta T$ needed to grow the glacier to the $13 \mathrm{ka}$ moraine without a change in precipitation $(x$-intercept), with the optimal parameter set yielding a $\Delta T$ of $-2.7^{\circ} \mathrm{C}$.

\begin{tabular}{llll}
\hline Parameter & Symbol & Value & $\Delta T\left({ }^{\circ} \mathrm{C}\right)$ \\
\hline Snow albedo & $\alpha_{\text {snow }}$ & 0.67 & -3.3 \\
& & 0.77 & -2.1 \\
Snow/rain temperature threshold $\left({ }^{\circ} \mathrm{C}\right)$ & $T_{\mathrm{s}}$ & 0 & -3.0 \\
& & 2 & -2.5 \\
Temperature lapse rate $\left({ }^{\circ} \mathrm{C} \mathrm{km}^{-1}\right)$ & $\mathrm{d} T / \mathrm{d} z$ & -6 & -3.0 \\
Roughness parameter for ice $(\mathrm{m})$ & $Z_{\text {ice }}$ & 0.002 & -2.7 \\
& & 0.008 & -2.8 \\
Roughness parameter for snow $(\mathrm{m})$ & $Z_{\text {snow }}$ & 0.0005 & -2.7 \\
Incoming shortwave radiation $(\mathrm{ka})$ & & 0.002 & -2.8 \\
& & 10 & -2.7 \\
Typical sliding velocity $\left(\mathrm{m} \mathrm{a}^{-1}\right)$ & & 18 & -2.7 \\
& $U_{\mathrm{c}}$ & 10 & -2.7 \\
Glen's flow law coefficient $\left(\mathrm{Pa}^{-3} \mathrm{a}^{-1}\right)$ & $A$ & 30 & -2.7 \\
& & $1 \mathrm{e}^{-16}$ & -2.7 \\
& & $1 \mathrm{e}^{-18}$ & -2.7 \\
\hline
\end{tabular}

an increase in precipitation. For example, a smaller $\Delta T$ of $-1.5{ }^{\circ} \mathrm{C}$ requires a coincident increase in $\Delta P$ of $80 \%$ to achieve the $13 \mathrm{ka}$ glacier extent.

In summary, the model simulations in experiment 1 suggest a temperature reduction of $2.7 \pm 0.6{ }^{\circ} \mathrm{C}$ sustained for a century is needed to produce the mapped extent without a change in precipitation. The optimal parameter set curve shows a $\Delta T$ of $-3.2{ }^{\circ} \mathrm{C}$ when $\Delta P$ is $-20 \%$ and $-2.3{ }^{\circ} \mathrm{C}$ when $\Delta P$ is $+20 \%$. Our palaeoclimate estimates are most affected by changes in the $T_{\mathrm{S}}$ and $\alpha_{\text {snow }}$ parameters. The modelled glacier geometry and ELA are very similar to previous reconstructions (Fig. 3d) based on geomorphology and AAR methods (Kaplan et al., 2010).

\subsection{Experiment 2: transient run driven by chironomid-derived temperature reconstructions}

The second experiment of our study was to run four timedependent simulations of glacier extent forced by the different BST chironomid-derived temperature reconstructions (Vandergoes et al., 2008). The resulting glacier length changes were then compared with the mapped and dated moraine sequence in Fig. 3a. Fig. 5 shows the PLS-smooth BST $\Delta T$ (present-day temperature is $\Delta T=0{ }^{\circ} \mathrm{C}$ ) from 15 to $11 \mathrm{ka}$, and the lower plot shows the corresponding change in glacier length. The $13 \mathrm{ka}$ moraine position (in terms of glacier length) is represented on Fig. 5 by the orange diamond with the error bars corresponding to the age of the moraine derived independently using surface exposure dating by Kaplan et al. (2010).

From 15 to $14 \mathrm{ka}$, temperature in the PLS-smooth chironomid model varies between +0.5 and $-2.5^{\circ} \mathrm{C}$ relative to the present. In response to this temperature forcing, the modelled glacier fluctuates between a length of $1640 \mathrm{~m}$ (about $100 \mathrm{~m}$ short of the moraine) and ice-free conditions. Ice persists at the headwall with a $\Delta T=-1{ }^{\circ} \mathrm{C}$, which supports our modern ELA estimate and the regional interpretation that the modern ELA lies just above the highest parts of the Irishman basin headwall (Porter, 1975b; Brazier et al., 1998; Lamont et al., 1999). The modelled glacier almost reaches the position of the $13 \mathrm{ka}$ moraine in response to the short-term $2.8{ }^{\circ} \mathrm{C}$ cooling at $13.8 \mathrm{ka}$ and retreats to within $250 \mathrm{~m}$ of the headwall by $13.3 \mathrm{ka}$ after a change in $\Delta T$ from -2 to $-1{ }^{\circ} \mathrm{C}$. Subsequent ice advances from 13.5 to $11 \mathrm{ka}$ are minor $(<250 \mathrm{~m})$ in the model run. The PLS-smooth forcing does not produce ice extents coinciding with the $12 \mathrm{ka}$ and $11.5 \mathrm{ka}$ moraines of Kaplan et al. (2010) (Fig. 5, represented by the yellow diamond and error bars). 

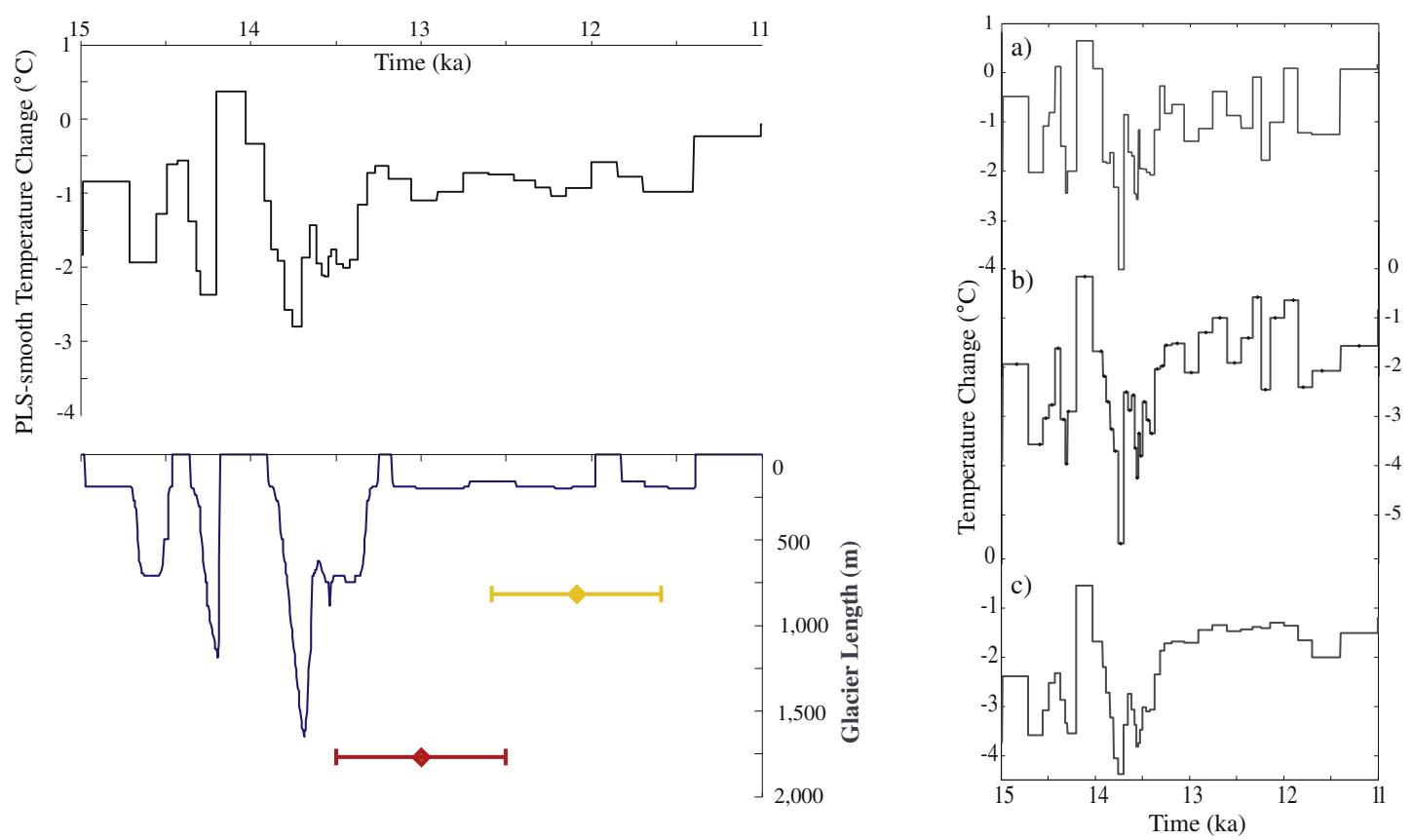

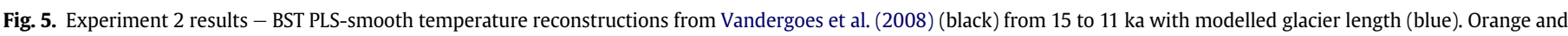

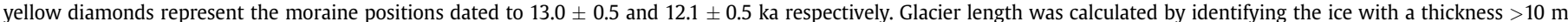

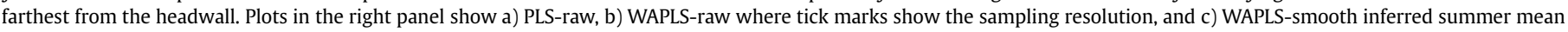
$\Delta T$ from 15 to $11 \mathrm{ka}$. Glacier lengths resulting from these three reconstructions extended beyond the 13 ka moraine and are not shown here.

All other BST temperature reconstructions produced modelled glacier extents (not shown) far beyond the moraine position during the coldest part of the curve, leading to a mismatch with the moraine data. PLS-raw data included a maximum $\Delta T$ of $-4{ }^{\circ} \mathrm{C}$, resulting in a modelled glacier length of $3000 \mathrm{~m}$, almost twice the geomorphically delimited length. WAPLS-raw and WAPLS-smooth included a maximum $\Delta T$ of -5.6 and $-4.4{ }^{\circ} \mathrm{C}$ respectively and both produced valley glaciers that were too extensive $(\sim 5500 \mathrm{~m}$ long). Model simulations with a greater magnitude of cooling, such as WAPLS-raw and WAPLS-smooth, also produced ice on the valley wall sides, which is not supported by the geomorphic evidence.

\section{Discussion}

We sought to improve Lateglacial palaeoclimate estimates derived from glacier reconstructions for central South Island by using a numerical modelling approach. Although this reconstruction is for a single site, ice in the Irishman basin would have responded to the same regional climatic changes as other glaciers in the central Southern Alps (Clare et al., 2002; Kaplan et al., 2010; Chinn et al., 2012). There is no present-day glacier in Irishman basin, and as a result we do not have site specific mass balance measurements with which to compare our results against directly, thereby tuning the model to this site. We do use temperature data from an automatic weather station setup in Irishman basin to determine appropriate seasonal lapse rates. The modelled 'equilibrium-line altitude' is above the ridge elevation, which is similar to previously interpolated ELAs (Chinn, 1995). Moreover, the model has been tuned and tested for other New Zealand glaciers (Anderson et al., 2010; Anderson and Mackintosh, 2012).

At present, Irishman basin has an annual mean temperature of $\sim 1.2^{\circ} \mathrm{C}$, and a cooling of only $1^{\circ} \mathrm{C}$ results in small glaciers developing at the headwall, which suggest that this site is ideal for recording even minor past shifts in climate. Our model successfully reproduced ice extent matching the moraine record with an estimated $\Delta T$ of $-2.7 \pm 0.6^{\circ} \mathrm{C}$, which supports previous evidence of a cold event in New Zealand during the ACR (e.g., Porter, 1975a; Hajdas et al., 2006; Carter et al., 2008; Putnam et al., 2010). There are a number of model parameter values that are uncertain for palaeoclimate simulations (Table 2) and we presented their effect on the modelling results (Fig. 4).

Ice extent and ELA reconstructions using the AAR method from Kaplan et al. (2010) are compared to our modelled ice extent and ELA in Fig. 3d. Our modelled area extent $\left(1.8 \mathrm{~km}^{2}\right)$ matches more closely with the smaller ice reconstruction (K1), whereas our model-based ELA estimate of $2000 \pm 40 \mathrm{~m}$ asl is closer to the larger reconstruction (K2), which gave an ELA of $1980 \pm 40 \mathrm{~m}$ asl. This is because the AAR (automatically) calculated by the mass balance model was 0.58 , compared to the 0.67 assumed by Kaplan et al. (2010). However, within uncertainties, all three reconstructions yield identical or similar extents, ELAs, and ice thicknesses. The agreement between the methods supports the use of the AAR method on glaciers in a simple topographic context with a well expressed geomorphic moraine record. Our estimated ELA lowering from the present day is $\sim 400 \mathrm{~m}$ for Irishman basin, which is similar to the ELA lowering derived for the Birch Hill event (500 $\mathrm{m}$ ) in the Tasman valley (Porter, 1975a), which is also dated to 13.1 ka (Putnam et al., 2010).

The transient simulations, using BST temperatures and moraine age and position as constraints, show an advance/retreat pattern in Irishman glacier from 15 to $11 \mathrm{ka}$. The modelled glacier advances to within $100 \mathrm{~m}$ of the moraine during the BST cold period $(\Delta T=-2$ to $-3{ }^{\circ} \mathrm{C}$ between 13.9 and $13.4 \mathrm{ka}$ ) and retreats to within $240 \mathrm{~m}$ of the headwall when the BST $\Delta T$ increases to $-1{ }^{\circ} \mathrm{C}(\sim 13.3 \mathrm{ka})$. The $2-3{ }^{\circ} \mathrm{C}$ cooling persisting for $\sim 500$ years from the chironomid record is sufficient to grow Irishman glacier out to the $13 \mathrm{ka}$ moraine. The timing of the simulated glacier retreat overlaps within error with the moraine age $(13 \pm 0.5 \mathrm{ka})$ (Fig. 5). A poorer match, however, is achieved for the 12 and 11.5 ka moraines, where the simulated glacier extent is $\sim 500 \mathrm{~m}$ from the $12 \mathrm{ka}$ moraine. 
This mismatch occurs because the BST temperature decrease is not of sufficient magnitude to produce the inferred glacier extent. The 12 ka temperature decrease might not be appropriately captured in the BST record due to lower sampling resolution during that time.

Overall, we see a good match between the chironomid-derived temperature reconstruction and the ACR moraine position via our modelling results. The brief cool spike from the PLS-smooth (Fig. 5) results in a glacier extent near the moraine, but predates the moraine age. Small mismatches in the chironomid and moraine records may reflect model, moraine dating, or BST age-model uncertainties, but could also reflect differences in response of each proxy to climate. We point out that chironomid- and glacierderived palaeoclimate records are inherently different, because they respond on different time scales and, perhaps, emphasise different characteristics of temperature change (e.g., tarn temperature versus glacier micro-climate). Yet, despite potential differences, these proxies both appear to be predominantly reflecting changes in temperature of approximately the same magnitude during the ACR.

The modelling results presented in this paper supports the idea that the temperature during the ACR was $2-3{ }^{\circ} \mathrm{C}$ cooler than today in New Zealand. This temperature change estimate overlaps, within error, with a temperature change estimate of $3-4{ }^{\circ} \mathrm{C}$ cooler than today, reported by Anderson and Mackintosh (2006) for the Franz Josef Glacier advance to the Waiho Loop during the Lateglacial. Our results are also consistent with published pollen studies (Newnham and Lowe, 2000; Turney et al., 2003; Vandergoes and Fitzsimons, 2003; Hajdas et al., 2006), and regional sea-surface temperature records (Carter and Cortese, 2009; Sikes et al., 2009) that suggest a temporary reversal of the deglaciation warming trend occurred in New Zealand during the Lateglacial.

\section{Conclusions}

We simulated a small glacier in the central Southern Alps to infer the local climate change that occurred during the ACR using a coupled energy-balance and ice-flow model. We show that:

1. Our simulated equilibrium-line altitude is $2000 \pm 40 \mathrm{~m}$ asl, which agrees within error with the traditional AAR method of reconstruction (1980 $\pm 40 \mathrm{~m}$ asl (Kaplan et al., 2010)). Our estimated Lateglacial ELA is $400 \mathrm{~m}$ lower than the modelled modern ELA of $2400 \pm 40 \mathrm{~m}$.

2. A $\Delta T$ (temperature change from today) of $-2.7 \pm 0.6{ }^{\circ} \mathrm{C}$ was required to simulate the ACR extent of Irishman glacier assuming no change in precipitation from present day.

3. The optimal parameter set curve shows a $\Delta T$ of $-2.3^{\circ} \mathrm{C}$ when $\Delta P$ (precipitation change from today) is $+20 \%$ and $-3.2{ }^{\circ} \mathrm{C}$ when $\Delta P$ is $-20 \%$.

4. The transient simulation of Irishman glacier length from 15 to $11 \mathrm{ka}$, driven by a chironomid-derived temperature reconstruction (Vandergoes et al., 2008), showed advance to and retreat from the 13 ka moraine.

5. Our model-based temperature reconstructions are compatible with other proxy records from New Zealand that show temperatures during the ACR were cooler than today.

\section{Acknowledgements}

Funding was provided by the New Zealand Government under a New Zealand International Research Doctoral Scholarship, by the Comer Science and Education Foundation and by Victoria University of Wellington, including the Antarctic Research Centre, the School of Geography, Environment and Earth Sciences, and the
Science Faculty Research Committee. M. Vandergoes and D. Barrell were supported by GNS Science's Direct Crown Funded Programme 'Global Change through Time'. We thank S. Stuart for providing his Southern Alps precipitation surface and R. Dadic, N. Golledge, H. Horgan, and K. Sattler for helpful discussions during the preparation of this paper. We also appreciate the helpful comments from M. Plummer and an anonymous reviewer. This publication is LDEO contribution number 7618 .

\section{References}

Alloway, B.V., Lowe, D.J., Barrell, D.J.A., Newnham, R.M., Almond, P.C., Augustinus, P.C., Bertler, N.A.N., Carter, L., Litchfield, N.J., McGlone, M.S., Shulmeister, J., Vandergoes, M.J., Williams, P.W., 2007. Towards a climate event stratigraphy for New Zealand over the past 30000 years (NZ-INTIMATE project). Journal of Quaternary Science 22, 9-35.

Anderson, B., Lawson, W.J., Owens, I.F., Goodsell, B., 2006. Past and future mass balance of Ka Roimata o Hine Hukatere (Franz Josef Glacier). Journal of Glaciology 52, 597-607.

Anderson, B., Mackintosh, A., 2006. Temperature change is the major driver of lateglacial and Holocene glacier fluctuations in New Zealand. Geology 34, 121-124.

Anderson, B., Mackintosh, A., 2012. Controls on mass balance sensitivity of maritime glaciers in the Southern Alps, New Zealand: the role of debris cover. Journal of Geophysical Research 117, F01003.

Anderson, B., Mackintosh, A., Stumm, D., George, L., Kerr, T., Winter-Billington, A., Fitzsimons, S., 2010. Climate sensitivity of a high-precipitation glacier in New Zealand. Journal of Glaciology 56, 114-128.

Barrell, D.J.A., Andersen, B.G., Denton, G.H., 2011. Glacial Geomorphology of the Central South Island, New Zealand. GNS Science Monograph, 27. GNS Science, Lower Hutt, New Zealand.

Barrows, T.T., Juggins, S., De Deckker, P., Calvo, E., Pelejero, C., 2007. Long-term sea surface temperature and climate change in the Australian-New Zealand region. Paleoceanography 22, PA2215.

Berger, A., Loutre, M.F., 1991. Insolation values for the climate of the last 10 million years. Quaternary Science Reviews 10, 297-317.

Birkeland, P.W., 1982. Subdivision of Holocene glacial deposits, Ben Ohau Range, New Zealand, using relative-dating methods. Geological Society of America Bulletin 93, 433-449.

Brazier, V., Kirkbride, M.P., Owens, I.F., 1998. The relationship between climate and rock glacier distribution in the Ben Ohau Range, New Zealand. Geografiska Annalers 80, 193-207.

Brock, B.W., Willis, I.C., Sharp, M.J., 2006. Measurement and parameterization of aerodynamic roughness length variations at Haut Glacier d'Arolla, Switzerland. Journal of Glaciology 52, 281-297.

Burrows, C.J., Russell, J.B., 1990. Aranuian vegetation history of the Arrowsmith Range, Canterbury 1. Pollen diagrams, plant macrofossils, and buried soils from Prospect Hill. New Zealand Journal of Botany 28, 323-345.

Carter, L., Cortese, G., 2009. Change in the Southern Ocean: responding to Antarctica. PAGES News 17, 30-32.

Carter, L., Manighetti, B., Ganssen, G., Northcote, L., 2008. Southwest Pacific modulation of abrupt climate change during the Antarctic cold reversal - Younger Dryas. Palaeogeography, Palaeoclimatology, Palaeoecology 260, 284-298.

Chinn, T., Fitzharris, B.B., Willsman, A., Salinger, M.J., 2012. Annual ice volume changes 1976-2008 for the New Zealand Southern Alps. Global and Planetary Change 92-93, 105-118.

Chinn, T.J., 1996. New Zealand glacier responses to climate change of the past century. New Zealand Journal of Geology and Geophysics 39, 415-428.

Chinn, T.J.H., 1995. Glacier fluctuations in the Southern Alps of New Zealand determined from snowline elevations. Arctic and Alpine Research 27, 187-198.

Clare, G.R., Fitzharris, B.B., Chinn, T.J.H., Salinger, M.J., 2002. Interannual variation in end-of-summer snowlines of the Southern Alps of New Zealand, and relationships with Southern Hemisphere atmospheric circulation and sea surface temperature patterns. International Journal of Climatology 22, 107-120.

Dieffenbacher-Krall, A.C., Vandergoes, M.J., Denton, G.H., 2007. An inference model for mean summer air temperatures in the Southern Alps, New Zealand, using subfossil chironomids. Quaternary Science Reviews 26, 2487-2504.

Eisenman, I., Huybers, P., 2006. Integrated Summer Insolation Calculations [Online] Available from: http://www.gps.caltech.edu/ ian/code/index.html.

EPICA Community Members, 2006. One-to-one coupling of glacial climate variability in Greenland and Antarctica. Nature 444, 195-198. http://dx.doi.org/ 10.1038/nature05301.

Fitzharris, B., Lawson, W., Owens, I., 1999. Research on glaciers and snow in New Zealand. Progress in Physical Geography 23, 469-500.

Fitzsimons, S.J., 1997. Late-glacial and early Holocene glacier activity in the Southern Alps, New Zealand. Quaternary International 38/39, 69-76.

Griffiths, G.A., McSaveney, M.J., 1983. Distribution of mean annual precipitation across some steepland regions of New Zealand. New Zealand Journal of Science 26, 197-209.

Hajdas, I., Lowe, D.J., Newnham, R.M., Bonani, G., 2006. Timing of the late-glacial climate reversal in the Southern Hemisphere using high-resolution radiocarbon chronology for Kaipo bog, New Zealand. Quaternary Research 65, 340-345. 
Henderson, R.D., Thompson, S.M., 1999. Extreme rainfalls in the Southern Alps of New Zealand. Journal of Hydrology (NZ) 38, 309-330.

Hindmarsh, R.C.A., Le Meur, E., 2001. Dynamical processes involved in the retreat of marine ice sheets. Journal of Glaciology 47, 271-282.

Hock, R., 2005. Glacier melt: a review of processes and their modelling. Progress in Physical Geography 29, 362-391.

Hubbard, A., Hein, A.S., Kaplan, M.R., Hulton, N.R., Glasser, N., 2005. A modelling reconstruction of the last glacial maximum ice sheet and its deglaciation in the vicinity of the Northern Patagonian Icefield, South America. Geografiska Annaler: Series A, Physical Geography 87, 375-391.

Ivy-Ochs, S., Schlüchter, C., Kubik, P.W., Denton, G.H., 1999. Moraine exposure dates imply synchronous Younger Dryas glacier advances in the European Alps and in the Southern Alps of New Zealand. Geografiska Annaler 81, 313-323.

Kalnay, E., Kanamitsu, M., Kistler, R., Collins, W., Deaven, D., Gandin, L., Iredell, M., Saha, S., White, G., Woollen, J., Zhu, Y., Chelliah, M., Ebisuzaki, W., Higgins, W., Janowiak, J., Mo, K.C., Ropelewski, C., Wang, J., Leetmaa, A., Reynolds, R., Jenne, R., Joseph, D., 1996. The NMC/NCAR 40-year reanalysis project. Bulletin of the American Meteorological Society 77, 437-471.

Kaplan, M.R., Schaefer, J.M., Denton, G.H., Barrell, D.J.A., Chinn, T.J.H., Putnam, A.E., Andersen, B.G., Finkel, R.C., Schwartz, R., Doughty, A.M., 2010. Glacier retreat in New Zealand during the Younger Dryas stadial. Nature 467, 194-197.

Kessler, M.A., Anderson, R.S., Stock, G.M., 2006. Modeling topographic and climatic control of east-west asymmetry in Sierra Nevada glacier length during the last glacial maximum. Journal of Geophysical Research 111, F02002.

Klok, E.J., Oerlemans, J., 2002. Model study of the spatial distribution of the energy and mass balance of Morteratschgletscher, Switzerland. Journal of Glaciology 48, 505-518.

Laabs, B.J.C., Plummer, M.A., Mickelson, D.M., 2006. Climate during the last glacial maximum in the Wasatch and southern Uinta Mountains inferred from glacier modelling. Geomorphology 75, 300-317.

Lamont, G.N., Chinn, T.J., Fitzharris, B.B., 1999. Slopes of glacier ELAs in the Southern Alps of New Zealand in relation to atmospheric circulation patterns. Global and Planetary Change 22, 209-219.

Le Meur, E., Gagliardini, O., Zwinger, T., Ruokolainen, J., 2004. Glacier flow modelling: a comparison of the shallow ice approximation and the full-stokes solution. Comptes Rendus Physique 5, 709-722.

Leysinger Vieli, G.J.M.C., Gudmundsson, G.H., 2004. On estimating length fluctuations of glaciers caused by changes in climatic forcing. Journal of Geophysical Research 109, F01007.

Mathieu, R., Chinn, T., Fitzharris, B., 2009. Detecting the equilibrium-line altitudes of New Zealand glaciers using ASTER satellite images. New Zealand Journal of Geology and Geophysics 52, 209-222.

McGlone, M.S., 1995. Lateglacial landscape and vegetation change and the Younger Dryas climate oscillation in New Zealand. Quaternary Science Reviews 14, 867-881.

McGlone, M.S., Turney, C.S.M., Wilmshurst, J.M., 2004. Late-glacial and Holocene vegetation and climatic history of the Cass Basin, central South Island, New Zealand. Quaternary Research 62, 267-279.

McGlone, M.S., Turney, C.S.M., Wilmshurst, J.M., Renwick, J., Pahnke, K., 2010. Divergent trends in land and ocean temperature in the southern ocean over the past 18,000 years. Nature Geoscience 3, 622-626.

McGregor, V.R., 1967. Holocene moraines and rock glaciers in the central Ben Ohau Range, south Canterbury, New Zealand. Journal of Glaciology 6, 737-748.

Neale, S.M., Fitzharris, B.B., 1997. Energy balance and synoptic climatology of a melting snowpack in the Southern Alps, New Zealand. International Journal of Climatology 17, 1595-1609.

Newnham, R.M., Lowe, D.J., 2000. Fine-resolution pollen record of late-glacial climate reversal from New Zealand. Geology 28, 759-762.

Newnham, R.M., Lowe, D.J., Giles, T., Alloway, B.V., 2007. Vegetation and climate of Auckland, New Zealand, since ca. 32000cal. yr ago: support for an extended LGM. Journal of Quaternary Science 22, 517-534.
Newnham, R.M., Vandergoes, M.J., Sikes, E., Carter, L., Wilmshurst, J.M., Lowe, D.J., McGlone, M.S., Sandiford, A. Does the bipolar seesaw extend to the terrestrial southern mid-latitudes? Quaternary Science Reviews, in this issue.

NIWA, Retrieved, 2009. CliFlo: NIWA's National Climate Database on the Web. Website: http://cliflo.niwa.co.nz/.

Oerlemans, J., 1992. Climate sensitivity of glaciers in southern Norway: application of an energy-balance model to Nigardsbreen, Hellstugubreen, and Alfotbreen. Journal of Glaciology 38, 223-232.

Oerlemans, J., 2001. Glaciers and Climate Change. A.A. Balkema Publishers, Amsterdam.

Oerlemans, J., 2005. Extracting a climate signal from 169 glacier records. Science 308, 675-677.

Oerlemans, J., Grisogono, W., 2002. Glacier winds and parameterisation of the related surface heat fluxes. Tellus 54A, 440-452.

Pahnke, K., Zahn, R., Elderfield, H., Schulz, M., 2003. 340,000-year centennialscale marine record of southern hemisphere climatic oscillation. Science 301, 948-952.

Paterson, W.S.B., 1994. The Physics of Glaciers, third ed. Pergamon, Oxford.

Plummer, M.A., Phillips, F.M., 2003. A 2-D numerical model of snow/ice energy and ice flow for paleo climatic interpretation of glacial geomorphic features. Quaternary Science Reviews 22, 1389-1406.

Porter, S.C., 1975a. Equilibrium-line altitudes of late Quaternary glaciers in the Southern Alps, New Zealand. Quaternary Research 5, 27-47.

Porter, S.C., 1975b. Glaciation limit in New Zealand's Southern Alps. Arctic and Alpine Research 7, 33-37.

Putnam, A.E., Denton, G.H., Schaefer, J.M., Barrell, D.J.A., Andersen, B.G., Finkel, R.C., Schwartz, R., Doughty, A.M., Kaplan, M.R., Schlüchter, C., 2010. Glacier advance in southern middle-latitudes during the Antarctic Cold Reversal. Nature Geoscience 3, 700-704.

Sikes, E.L., Howard, W.R., Samson, C.R., Mahan, T.S., Robertson, L.G., Volkman, J.K., 2009. Southern Ocean seasonal temperature and Subtropical Front movement on the South Tasman Rise in the late Quaternary. Paleoceanography 24, PA2201.

Stuart, S., 2011. Observations and Modelling of Precipitation in the Southern Alps of New Zealand. Master's thesis. Victoria University of Wellington, New Zealand.

Suggate, R.P., 1990. Late Pliocene and Quaternary glaciations of New Zealand. Quaternary Science Reviews 9, 175-197.

Tait, A., Zheng, X., 2007. Analysis of the Spatial Interpolation Error Associated with Maps of Median Annual Climate Variables. Website: http://www.niwa.co.nz/ sites/default/files/import/attachments/Climate_Maps_Error_Analysis.pdf.

Turney, C.S.M., McGlone, M.S., Wilmshurst, J.M., 2003. Asynchronous climate change between New Zealand and the North Atlantic during the last deglaciation. Geology 31, 223-226.

Turney, C.S.M., Roberts, R.G., de Jonge, N., Prior, C., Wilmshurst, J.M., McGlone, M.S. Cooper, J., 2007. Redating the advance of the New Zealand Franz Josef Glacier during the last termination: evidence for asynchronous climate change. Quaternary Science Reviews 26, 3037-3042.

Vandergoes, M.J., Dieffenbacher-Krall, A.C., Newnham, R.M., Denton, G.H., Blaauw, M., 2008. Cooling and changing seasonality in the Southern Alps, New Zealand during the Antarctic cold reversal. Quaternary Science Reviews 27, 589-601.

Vandergoes, M.J., Fitzsimons, S.J., 2003. The last glacial-interglacial transition (LGIT) in south Westland, New Zealand: paleoecological insight into mid-latitude Southern Hemisphere climate change. Quaternary Science Reviews 22, $1461-$ 1476.

Williams, P., King, D., Zhao, J.X., Collerson, K., 2005. Late Pleistocene to Holocene composite speleothem ${ }^{18} \mathrm{O}$ and ${ }^{13} \mathrm{C}$ chronologies from South Island, New Zealand did a global Younger Dryas really exist? Earth and Planetary Science Letters 230, 301-317.

Winkler, S., Chinn, T., Gärtner-Roer, I., Nussbaumer, S.U., Zemp, M., Zumbühl, H.J., 2010. An introduction to mountain glaciers as climate indicators with spatial and temporal diversity. Erdkunde 64, 97-118. 